\title{
THE WIRELESS SENSOR NETWORK CONCEPT FOR MEASUREMENT OF WATER QUALITY IN WATER STREAMS
}

\author{
L’udmila MACEKOVÁ, Matej ŽIGA \\ Department of Electronics and Multimedia Communications, Faculty of Electrical Engineering and Informatics, \\ Technical University of Košice, Letná 9, 04200 Košice, Slovak Republic, tel. +421 55602 4108, e-mail: ludmila.macekova@tuke.sk
}

\begin{abstract}
This article describes main aspects and steps of our design of water quality monitoring wireless sensor network. Interconnections between the ecologic-environmental, biologic-chemical measurements and electronic-telecommunications areas can be found in this matter. is Both the consultation with environmental specialists and data from the legislative documents from this area are unavoidable parts of such study. The result of study is selection of the measure indicators of water quality, proposal of suitable sensors, measurement method and architecture of the wireless sensor network. This work is a part of international crossborder co-operation, with the aim to build a system for both monitoring the ecologic-biological state of the cross-border river and early warning in case of an ecological disaster.
\end{abstract}

Keywords: water quality indicator, sensor, water quality probe, wireless sensor network

\section{INTRODUCTION}

The quality of all natural water bodies and sources has direct or indirect impact on human health, therefore, its watching is important, broadly elaborated and it is a subject of several scientific and practical branches.

There are more particular purposes and goals of measuring water parameters, as follows: monitoring the state of rivers crossing a country border, monitoring parameters of water streams flowing near significant potential pollutants, as human seats, industrial or agricultural plants, watching parameters of water bodies designated for drinking, watering, fish farming, etc. Related national and international norms and standards contain water quality indicators (physical, chemical and biological), their limits, locations of measurements, sampling frequency, and measuring and evaluating methods depending on several points of view as it was mentioned above.

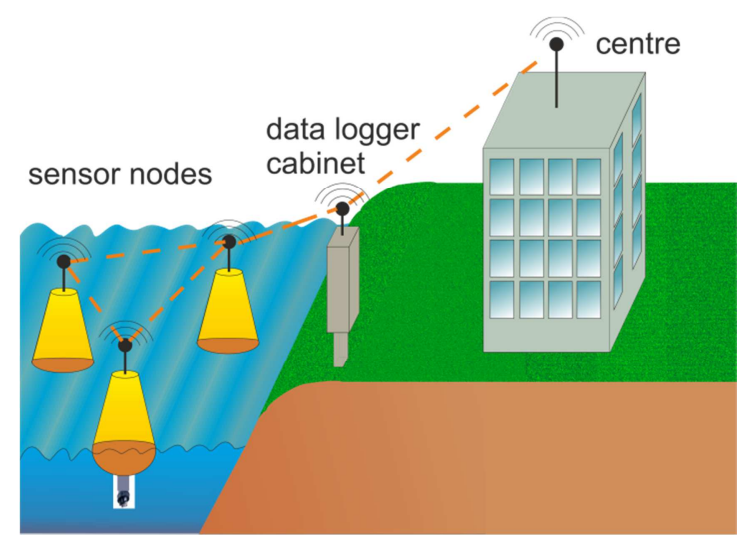

Fig. 1 Wireless sensor network for surface water quality measurement

We are focusing on the design of a wireless sensor network (Fig. 1) for the continuous monitoring of water quality of the Danube River, based on electrical methods, in the frame of the scientific project (see in
Acknowledgments). Hence, we are primarily interested in the electrical aspects of measurements, selection of a few main parameters, their limits, locations and the methodology of the measurement. Subsequently, in the frame of the project, we intend to design a complete wireless sensor network to transfer, gather and process measured data by the required mode. Alarm message will be one of the required output values of system in case of reaching any dangerous limit. Sensor nodes for baseline monitoring and watching system must be minimal energy and maintenance demanding.

Although our aim is to monitor surface waters, mainly the river body (Danube), we do not exclude the extension of the application of our coming design also to other water bodies and for various purposes.

Following parts of the article describe main quality indicators monitored in surface waters, respective European and Slovak legislative frame, principles of selected parameters and of probes to their measurements and our concept of design of the wireless sensor network for the continual measurement and for the alarm messaging in early warning system.

\section{TYPES OF POLLUTION OF WATER STREAMS AND SELECTION OF PARAMETERS OF WATER QUALITY MEASUREMENTS}

These issues are subject matter of more specialized water management branches, together with environmentalism, biology, chemistry, geology, etc.

As a result of acid rainfall, wastewater, land use and various human activities more different bacteria, organic substances, chlorine compounds, petroleum matters (NEL), hydrocarbons, nitrates and heavy metals $(\mathrm{Hg}, \mathrm{Pb}$, etc.) can be found in water streams. They can deteriorate life conditions of the natural fauna and flora and for human. Presence of different matters dissolved or scattered in the water, affects its acid-base equilibrium ( $\mathrm{pH}$ parameter), conductivity, hardness, colour, opacity or cloud, smell, and temperature, and sometimes foam can also be found on water surface. These very heterogeneous 
types of pollution are listed in the water management standards, where the methods of their evaluation can be found, too. For our purpose, we must point out some main measurable parameters of surface waters (main indicators or principal parameters of water quality) and study principles of their measurements, evaluating, and danger limits.

Some water quality measurement network projects were described for example in [13] or [37]. According to these and references from producers and from environmental institutions [7], [8], [9], [10], we have decided to measure only a few indicators of the water quality, as follows:

- temperature

- $\mathrm{pH}$

- $\quad$ oxidation-reduction parameter (REDOX)

- conductivity

- dissolved oxygen.

These indicators are interesting from the general environmental aspect. Their variations mostly correlate with variations of other specific (chemical and biological) parameters or result from them [10], [13], etc. These indicators can indicate meaningful changes in water streams and can be used to initiate an alarm system. Predominantly, they are continuously watched and evaluated in automatic or semiautomatic way today, using more or less sophisticated robust equipment. An employee must control and/or log the data from the probes periodically in time intervals of a few days or weeks.

\section{LEGISLATIVE FRAME OF WATER QUALITY MONITORING}

The legislative frame is important. Local and national authorities for water management and monitoring in Slovakia are as follows:

- $\quad$ SHMI (Slovak HydroMeteorological Institute),

- WRI (Water Research Institute - Výskumný ústav vodného hospodárstva),

- SWME (Slovak Water Management Enterprise Slovenský vodohospodársky podnik) and its relevant branch river basins managements.

They are mostly the government institutions. They collaborate in common commissions, participate in preparing the laws (e.g. [6]), government regulations (as such as [5]), water management plans, norms and standards.

The document "Water Plan of the Slovak Republic" [11] implements also the directives of the European Parliament and of the Council of The European Union [3], [4], and contains the tasks for all participants and responsible members. These documents also contain limits of particular parameters of the water quality.

We have consulted our intentions with the specialists from these institutions, and we have extracted many special information and values from the documents mentioned above.

\section{MAIN INDICATORS OF WATER QUALITY}

In this section, we introduce brief explanations of selected principal parameters of water quality in water streams: pH, REDOX parameter, dissolved oxygen, conductivity and temperature. Measurement principles and limits of the mentioned parameters established for the good quality water for the Danube River by [5] are described as well.

"Good quality" ranks second in scale of five in the ecological evaluation of the water streams quality [33].

Point of view for the followed explanations is in some cases rather chemical than electrical. Electrochemical processes of measurements convert these properties into an electronic signal.

Today's ambition of developers and producers is to use also the biochemical property vs. optoelectronic information/data relation. These optical methods use luminescent sensing dyes. Optical sensors, working with spectrometry principle are more comfortable and demand less calibration and maintenance. They are often used in parallel or before more precise electrochemical methods in a laboratory as well as for food control, etc.

Another principle is investigated and (e.g., in [30]) used: operation of the Ion-sensitive Field Effect Transistors (ISFETs), as a special class of the Chemicalsensitive FETs (ChemFETs). In the ISFET, an analysed solution is in direct contact with a gate insulator layer $\left(\mathrm{SiO}_{2}\right)$ over an electroactive membrane, and a metal reference electrode is immersed in the measured solution and operates as the metal gate (i.e., the electrode to control the conducting channel) [30]. For instance, the Microsens produces ISFET sensors [31] and the Hach Series Meters and Probes apply this phenomenon in their non-glass $\mathrm{pH}$ probes and multimeters [32].

\section{1. $\mathrm{pH}$ parameter}

In chemistry, the $\mathrm{pH}$ is a measure of the acidity or basicity of an aqueous solution, which correlates with the hydrogen ion $\mathrm{H}^{+}$activity $\mathrm{a}_{\mathrm{H}+}$, and also with the hydrogen ion concentration, expressed in the amount of the moles per litre, noted symbolically by the $\left[\mathrm{H}^{+}\right]$. The $\mathrm{pH}$ parameter is theoretically defined as the negative common logarithm of the hydrogen ion concentration [1], [2]:

$$
\left.\mathrm{pH}=-\log \left[\mathrm{H}^{+}\right] \quad \text { [without units }\right]
$$

The pure freshwater has the neutral $\mathrm{pH}$ (the hydrogen $\mathrm{H}^{+}$ion concentration equals the hydroxid $\mathrm{OH}^{-}$ concentration), with the value very close to 7 at $25^{\circ} \mathrm{C}$. That means the hydrogen ion concentration is $1.0 \times 10^{-7}$ moles/litre. Some other illustrative values of the $\mathrm{pH}$ are in the Table 1.

The $\mathrm{pH}$ can considerably decrease as a result of the leaching of organic acids from the decaying vegetation and the presence of the dissolved $\mathrm{CO}_{2}$. Thus, we talk about the soft water [1]. 
Table 1 The $\mathrm{pH}$ values of some water solutions [1]

\begin{tabular}{|l|l|l|}
\hline \multicolumn{1}{|c|}{ Type of solution } & \multicolumn{1}{|c|}{ Value of pH $[-]$} & Note \\
\hline \hline pure fresh water & about 7 & pH neutral \\
\hline drinking water & $<6.5,8.5>$ & \\
\hline sea water & close to 8 & \\
\hline acidic solutions & $<7$ & \\
\hline sour lemon juice & about 2 & \\
\hline strong cleaner sol. & $>13$ & \\
\hline basic solutions & $>7$ & alcaline sol. \\
\hline
\end{tabular}

We must emphasize, that the value of $\mathrm{pH}$ closely depends on the temperature of the solution, as follows:

If the equilibrium reaction of the water dissociation is

$\mathrm{H}_{2} \mathrm{O} \leftrightarrow \mathrm{H}^{+}+\mathrm{OH}^{-}$

then the equilibrium constant $\mathrm{K}_{\mathrm{w}}$ denotes the rate of this reaction, and is determined by:

$\mathrm{K}_{\mathrm{w}}=\left[\mathrm{H}^{+}\right]\left[\mathrm{OH}^{-}\right]$

The $\mathrm{K}_{\mathrm{w}}$ varies its value with the temperature. At $25^{\circ}$ $\mathrm{K}_{\mathrm{w}}$ has the value $1.01 \times 10^{-14}$ [23].

The more practical definition of the $\mathrm{pH}$ correlates with the electrometric mechanism of the $\mathrm{pH}$ measurement, and is standardized in accordance with the IUPAC Recommendations (International Union of Pure and Applied Chemistry). Here, the $\mathrm{pH}$ is proportional to the potential difference (or the measurable voltage) between both reference and indicating electrodes immersed in the measured water solution. The potential of the reference electrode is ideally independent of $\mathrm{pH}$ and the potential of the indicating electrode is directly proportional to $\mathrm{pH}$. The measured voltage $\mathrm{E}$ in millivolts is as follows (the Nernst equation [22]):

$\mathrm{E}=E_{\text {ind }}-E_{\text {ref }}=E_{T}^{\prime}+\mathrm{R}(\mathrm{T} / \mathrm{F}) \ln \left[H^{+}\right]$

where $E_{\text {ind }}$ is the voltage of the indicator electrode $(\mathrm{mV}), \mathrm{E}_{\mathrm{ref}}$ is the voltage of the reference electrode $(\mathrm{mV})$, $\mathrm{E}_{\mathrm{T}}^{\prime}$ is the temperature dependent constant $(\mathrm{mV}), \mathrm{R}$ is the gas constant $(8.3144 \mathrm{~J} / \mathrm{K}), \mathrm{T}$ is the absolute temperature $(\mathrm{K})$, and $\mathrm{F}$ is the Faraday's constant $\left(96485 \mathrm{C} \mathrm{mol}^{-1}\right)$.

This principle is mostly applied in the professional glass electrochemical $\mathrm{pH}$ probes.

\subsection{Conductivity}

Generally, measurement of the conductivity (CD) means the measuring the ionic (or the ionisable solutes) content of a solution [25].

The conductivity - more precisely, the specific conductance - in the $[\mathrm{S} / \mathrm{m}]$ - is defined as:

$C D=\frac{K_{\text {cell }}}{R} \frac{1}{1+\left(\frac{\alpha}{100}\right) *(T-25)}$

where

the $\mathrm{K}_{\text {cell }}$ is the cell constant in $\mathrm{m}^{-1}$ (it equals to $l / \mathrm{A}$, where the $l$ is the distance between the electrodes in the galvanic cell and the $\mathrm{A}$ is the area of the electrodes), $\mathrm{R}$ is the measured resistance in $\Omega, \alpha$ is the temperature compensation factor in $\%$ per ${ }^{\circ} \mathrm{C}$, and $\mathrm{T}$ is the temperature in ${ }^{\circ} \mathrm{C}[21]$.

However, mostly the $\mathrm{CD}$ is expressed in smaller units $(\mathrm{mS} / \mathrm{m}$ or $\mu \mathrm{S} / \mathrm{cm}$, etc., see Table 2$)$.

Table 2 Some selected values of conductivity [25].

\begin{tabular}{|l|l|l|l|}
\hline \multicolumn{1}{|c|}{$\begin{array}{c}\text { Type of } \\
\text { water }\end{array}$} & \multicolumn{1}{c|}{ CD } & \multicolumn{1}{|c|}{$\begin{array}{c}\text { Tempe } \\
\text { rature }\end{array}$} & \multicolumn{1}{c|}{ note } \\
\hline \hline $\begin{array}{l}\text { the Danube } \\
\text { River }\end{array}$ & $<70 \mathrm{mS} / \mathrm{m}$ & $<23^{\circ} \mathrm{C}$ & $\begin{array}{l}\text { for 2nd } \\
\text { degree of } \\
\text { quality [4] }\end{array}$ \\
\hline $\begin{array}{l}\text { drinking } \\
\text { water }\end{array}$ & $0.5-1 \mathrm{mS} / \mathrm{cm}$ & $25^{\circ} \mathrm{C}$ & \\
\hline pure water & $0.05 \mu \mathrm{S} / \mathrm{cm}$ & $25^{\circ} \mathrm{C}$ & \\
\hline
\end{tabular}

The conductivity probe provides a current or a voltage output, which must be measured by a high input impedance measurement equipment. We can also transform the output signal into the frequency value of the AC excited signal, when the conductivity sensor system uses an integrated timer. Accuracy and resolution of the conductivity measurements depend on chemical, physical, and electrical nonidealities, such as contamination of the sensor electrode surface, electrochemical effects and temperature dependence [20].

\subsection{REDOX, ORP}

The REDOX (reduction - oxidation) parameter or the ORP (the oxidation-reduction potential) is a measure, in millivolts, of the tendency of a chemical substance to oxidize or reduce another chemical substance [15]. The oxidation is the loss of electrons by an atom, molecule, or ion. It may or may not be accompanied by the addition of the oxygen, which is the origin of the term. The reduction is the gain of electrons by an atom, molecule, or ion.

When a substance is oxidized, its oxidation state increases, when it is reduced, its oxidation state decreases. These two reactions coexist together: electrons lost in oxidation must have another substance as a destination, and electrons gained in the reduction reactions have to come from a source. For example: oxidation (half-reaction):

$\mathrm{Fe}=\mathrm{Fe}^{+2}+2 \mathrm{e}^{-}$

reduction (half- reaction):

$\mathrm{Cl}_{2}+2 \mathrm{e}^{-}=2 \mathrm{Cl}^{-}$

overall reaction:

$\mathrm{Fe}+\mathrm{Cl}_{2}=>\mathrm{FeCl}_{2}$

The standard potential $\mathrm{E}^{\mathrm{o}}$ of redox couple determines how easily a substance is oxidized or reduced. The ORP can be calculated by the Nernst equation, and evaluated and measured in $\mathrm{mV}$ [15].

The REDOX ability of a solution depends on the temperature as well [15]. It also relates to the water purity in relation to life in water. A decreasing redox potential indicates a deterioration of the water quality. A system's reduction potential may change upon introduction of new 
species or when the concentration of existing species changes.

The ORP monitoring and controlling can intercept attendance of the cyanide, chlorine, chrome, etc. in water. Generally, it can detect presence of an oxidant or a reductant. The ORP is also measured to control biological growth (some destroying microorganisms in swimming pools using the chlorination, etc.).

Measured values of the ORP range from -2000 to $+2000 \mathrm{mV}$, with the typical accuracy of the measurement $5 \mathrm{mV}$. For example, the value of ORP recommended for the pool water is $+680 \mathrm{mV}$.

The $\mathrm{pH}$ is mostly controlled simultaneously with the ORP measurement.

\subsection{Dissolved oxygen}

Presence of oxygen is one of the necessary conditions of life. Level of the dissolved oxygen (DO) determines the life span of microorganisms in activated sludge basins which break down solid materials in the wastewater treatment. Measurement of dissolved oxygen is also important in lakes, streams and fish farming, to ensure healthy growth for the food industry.

Principle of the DO measurement can be again an electro chemical process in polargraphic or galvanic cells, or an luminescent method in LDO (Luminescent Dissolved Oxygen) probes [28].

For the Danube River in a good quality state (the $2^{\text {nd }}$ degree), there must be more than $7 \mathrm{mg}$ of oxygen per litre of the water [5]. Less than $5 \mathrm{mg} / \mathrm{l}$ content of the oxygen in water causes deterioration of health of fish [16], less than $2 \mathrm{mg} / \mathrm{l}$ causes their death.

\subsection{Temperature}

The temperature affects many physical, biological, and chemical characteristics of the water, as well of water streams. It influences the amount of the oxygen dissolved in water, the rate of the photosynthesis of water plants, the metabolic rate of animals, etc. The thermal pollution means increasing of water temperature, which can be of the various origin: water from warmed urban surfaces, waste waters, removing of trees from river banks, etc.

Because of environmental protection, resistance principle of thermometer must be used rather than the mercury thermometer. This means there is a sensor with some distinguished temperature depending resistor with resistance $\mathrm{R}$ at the temperature $\mathrm{T}$, as follows:

$R_{T}=R_{0} \cdot\left[1+\propto\left(T-T_{0}\right)\right]$

where $R_{0}$ is the resistance at the reference temperature $\mathrm{T}_{0}$, and $\alpha$ is the temperature coefficient of the resistor material.

The resistance of a metal caused by "defects" disturbing movement of electrons is used here. This property is stronger with arising temperature. The platinum is the known material, whose temperature dependent resistivity is used.

By [5] for the good state (the $2^{\text {nd }}$ degree) of Danube River, the water temperature must not exceed $23^{\circ} \mathrm{C}$ in the upper section of the stream on the Slovak territory.

\section{SENSORS}

Sensors and probes work mostly on electrochemical, principles, as it is mentioned above. This section only describes these principles. They are applied in the glass electrodes or generally in the so called ISE electrodes (Ion-Selective Electrodes) [17]. There are 3 components: an indicative electrode, a reference electrode and a semipermeable membrane, sensitive to a special chemical environment. The indicative electrode shows out some little electric potential when it is attended in the measured environment (gas, liquid, ground, etc.), depending on the activity of the measured ions. Ideally, the reference electrode does not change its electro-chemical potential during the measurement.

The electrodes are mostly rod like shaped, and can be used separately or can be set in the compact combined double electrode [22] (Fig. 4a). A relevant potential difference between of two electrodes appears and is measured by a voltmeter. This voltage is then computationally transformed into the value of a measured parameter [17] and indicated on a display.

Electrochemical $\mathrm{pH}$, conductance, dissolved oxygen, etc., probes must be generally carefully maintained in special manner, often cleaned and calibrated and must be stored in special solutions, as well. For this purpose buffers (solutions with defined properties) are unavoidable. Generally, measurements must be temperature compensated and often some other measurement must be realized together (REDOX with $\mathrm{pH}$ and temperature, etc.).

\section{1. pH sensors}

A potential difference between electrodes immersed in a tested solution is directly proportional to $\mathrm{pH}$ [2].

The calibration of measuring equipment must be considered and realised before measurement campaign. Calibrating process consists of two or more times repeated sequential immersions of the probe into calibrating solutions (buffers), with the aim to gain more calibration data. Buffers are stable solutions with exactly defined $\mathrm{pH}$ at the defined temperature. Buffers used for calibration must have different $\mathrm{pH}$, but in the interval of the supposed value of the measured solution. Two- or more-pointscalibration is known, depending on the required accuracy or on expected shape of the $\mathrm{pH}$-voltage relation, graphically illustrated by diagram. Mostly the dependency is considered roughly linear and then, it is demanding only two calibration points. After calibration, mathematical estimation of $\mathrm{pH}$ (by microcomputer) is applied at the temperature of tested liquid.

Consideration of temperature is necessary condition for a correct evaluation and comparison, so the temperature is usually measured simultaneously with the $\mathrm{pH}$.

The inner impedance of the probes is about $10^{8} \mathrm{ohm}$, so the input resistance of an amplifier is recommended $10^{12} \mathrm{ohm}$. The system must not send any current into the electrode to not create any voltage and to avoid disturbance or error [22]. 


\subsection{Conductivity sensors}

There are two basic types of sensors for conductivity measurement a contacting (conductive) sensor and an electrode-less (inductive) sensor.

The contacting sensors consist of two metal electrodes (stainless steel, titanic, or platinum) immersed in electrolyte solution. Depending on the concentration of ions in the solution (and also on geometric parameters, and temperature), a current of certain value starts to flow between the electrodes and can be recalculated into the value of conductivity.

Precise equipment can utilise four electrodes and/or the AC-current principle. This principle provides wider dynamic range and reduces errors due to the recombination of the ions on the electrodes, serial impedance of the wires and effect of contaminations of electrode surface [20].

The conductivity of liquids is measured with a measuring system that has two coaxially arranged electrodes.

In inductive conductivity measurement equipment, a transmitting toroid coil generates magnetic alternating field that induces ionic current in the ambient solution, depending on the conductance of the solution. In the receiver toroid coil, the current is induced, measured and evaluated by an analyser. The advantages of such design are as follows: the material of coils does not need to touch the solution and the solution can also contain big dispersed solid particles. This principle is suitable for measurement of the conductivity greater than approximatelly $15 \mu \mathrm{S} / \mathrm{cm}[26]$.

\subsection{REDOX or ORP sensor}

An ORP sensor consists of an ORP electrode and a reference electrode, and uses the potentiometric principle as $\mathrm{pH}$ measurement. The ORP is measured in millivolts, whereas the $\mathrm{pH}$ is without units. The measurement electrode is made of inert metal (platinum, sometimes gold), which, due to its low resistance, will give up electrons to an oxidant or accept electrons from a reductant. The ORP electrode potential is increased due to this mechanism and is equal to the ORP of the solution. The REDOX potential should be measured when electron activity of the sample and the sensor surface reach the equilibrium. This equilibrium depends on material and surface of the electrode and on the solution. The reference electrode is usually made of $\mathrm{Ag}-\mathrm{AgCl}$ [15].

\subsection{Dissolved oxygen probes}

The electrochemical cells of the dissolved oxygen probes consist of two different metals electrodes (e.g. lead, silver, gold or zinc and gold or silver) connected by the electrolyte solution through the semipermeable membrane, using external potential (in polargraphic cells) or without membrane and without the need of external source (in galvanic cells) [27]. In polargraphic cells the oxidation builds up a layer of oxide on the surface of the cathode or anode, and affects also the properties of the probe electrolyte solution. Therefore the maintenance and using of such probe is complicated.
The dissolved oxygen sensors with the optical principles measure interaction between the oxygen and certain luminescent dyes [24], [29].

\subsection{Thermometers}

As it was mentioned above, for the purpose of temperature measurements, but also for temperature compensation of other indicator measurements RTDs (Resistance Temperature Detectors) can be used. The thermometers are an unavoidable component part of water quality multimeters and probe systems.

The types as PT100, PT500, PT1000 are reliable professional sensors, which have been tested and utilised in many applications. Here, the temperature dependency of the resistance of the platinum is utilized [14], it enables measurement of the temperature in the range of -200 up to $+850{ }^{\circ} \mathrm{C}$ with the linear characteristic (Fig.2). Resistance rather than voltage is measured.
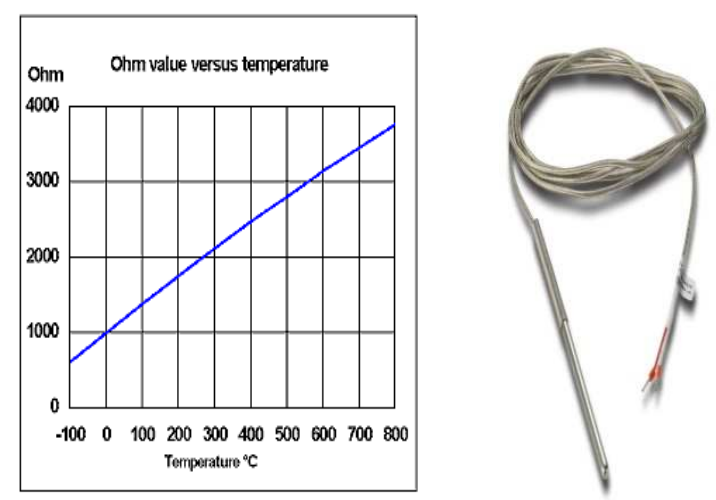

Fig. 2 Temperature dependency of platinum resistance in the Pt 1000 and the illustration of the thermometer construction [14], [36].

\subsection{Multimeters}

A number of hand-held measurement devices (like multimeters in Fig. 4b) are known, which are connectable to more types of probes, and can show or recalculate parameters mentioned above. They can serve for combined measurement methods (without and with a man attendant), and also for the calibration and the reference measurement. Multi-parameter multi-channel devices can measure a few parameters simultaneously. They can generate alarm at the exceeding limits, or in case, when it is needed to calibrate or maintenance the $\mathrm{pH}$ probe.

\subsection{Multiprobe systems}

Today, several producers in the area of water quality measurements offer freestanding probes, and also the sophisticated so called multiprobe systems, or multiparameter probes. The multiprobe system (e.g. [19] Fig. 4c) has a common base with the powering and communication interface, optionally, it can connect 3 or more (more than 10) probes for several water quality indicators. The multiprobe can have its own battery, a cleaning brush with automatic function, a protective cage and an outgoing connecting cable for the power supply and communication. These systems can be fastened to a 
buoy, and can measure continuously during intervals of a few weeks without maintenance.

\section{COMMUNICATIONS PROTOCOLS}

One from the RS-232 and SDI-12 communications protocols can be chosen for the communications between probes and basic electronics. They are mostly utilized for the setting, operational control and data logging.

RS-232 is a serial system, and an interface developed to communications between PC and other electronics. It is suitable for transmission over telephone lines. Bits are subsequently sent by one pair of the wires for each direction. This system is thought a good processed one and a completely collision-less physical layer.

SDI-12 [12] also stands for a serial data interface and communications protocol at 1200 baud speed. It is the standard for interface battery powered data recorders with micro-processor based sensors designed for the environmental data acquisition (EDA). An intelligent sensor typically takes measurement, makes computations based on the raw sensor reading, and outputs the measured data in engineering units. This system requires minimal current drain and it can use one data recorder with multiple sensors on a single cable. There can be microprocessor-based sensors that perform complex calibration algorithms or make internal computations. These requirements are necessary to acquire hydrologic data at remote sites, where most of them use battery powered data recorders to operate for long and unattended periods of time.

\section{METHODS OF MEASUREMENTS OF SELECTED WATER QUALITY PARAMETERS}

Only one case of the continuous monitoring of river water quality is known in Slovakia - monitoring of the Uh River status in the 90-ies [16].

In the USA, Canada, and the UK they evidently have more experience with complex measurements systems, such as probes and multiprobes mentioned above, continuously immersed in the water and provided digital data to a data-logger or data-centre by a connecting cable (for example [7], [8], [9], [10]). They shop their products also in other countries.

The problem of measurement methods is regulated by the regulations and standards mentioned above. Mostly certificated methods of measurements are required.

Generally, in the frame of those documents, surface water data measurements are mostly realised only a few times per year (once a month, etc.). The special cases are the temperature, level height, maybe other indicators at the specific area, and state of emergency, when the measuring must be realized much more often.

Contractual persons are another way to gain information about the actual state of a water body. They regularly watch the water body by subjective observations or by very simple measurement operations (appearance, level height, temperature), and record and send the data to the centre. These operators together with inhabitants also provide messages about sudden states of emergency, subsequently verified by certified measurements in the laboratory. Then, the responsible persons can launch an alarm, eventually.
Simplified measurement methods can be used for purpose of the continuous monitoring the water quality by our wireless sensor network. However, certified measurements in the laboratory must follow it for verifying data and for start the early warning system at limit values. Simplified method stands for the using robust probes and multiprobe systems, which can be submerged into the water, fixed on the buoy or at the riverbed. Our multiprobe (the core of the sensor node) must be completed by the wireless transceiver technology for the remote communications. Outgoing data coming from probes can be transformed by our custom microprocessor circuit or straight sent in the frame of message packet to the centre.

As we have found, the construction of reliable and robust measurement probes, maybe except the temperature sonde, is too demanding. Therefore it would be better to use the professional equipment (e.g. [19]).

\section{CONCEPT OF THE WIRELESS SENSOR NETWORK ARCHITECTURE}

Idea of our wireless sensor network for the water quality monitoring is presented in the Fig.3. The sensor nodes realized by multiprobes can be placed on the buoys, floating on the water surface. Data processing unit and wireless transceiver unit will be on the buoy, except probe systems. This equipment will transform the measured data and send them by the wireless communication link to the centre on the river bank, or/and to the remote centre with the laboratory. The wireless interconnection can be realized by a selected mobile communications network.

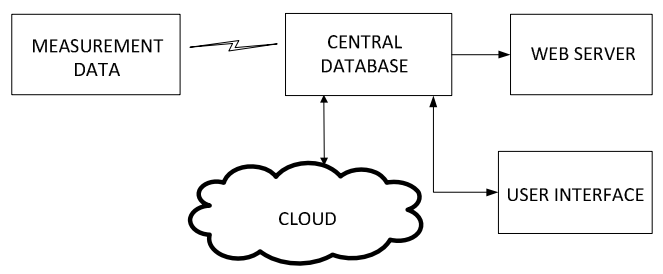

Fig. 3 Concept of architecture of designed water quality sensor network.

The remote centre will be equipped by (except the transceiver unit) the data store and data processing and analyse hardware. Naturally, communications must include also the link to the water quality laboratory for the manual verifying, analyse of the data and realisation the special steps at some defined results. Web pages with selected outgoing data and information will be the publicly accessed besides the authorize database and software.

Because of the huge amount of data, gained by the "continuous" measurements, and because of the requirement to save the long history of measurements, using the cloud storage method of data storing is not excluded.

\section{CONCLUSION}

In this article, main facts about water quality measurements were described in relation with aims of our 
HUSK project. More of these facts are optional for us (selecting of measured parameters, method of measuring,

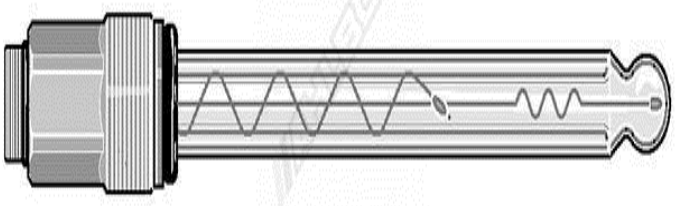

a) combined (double) electrode [35]

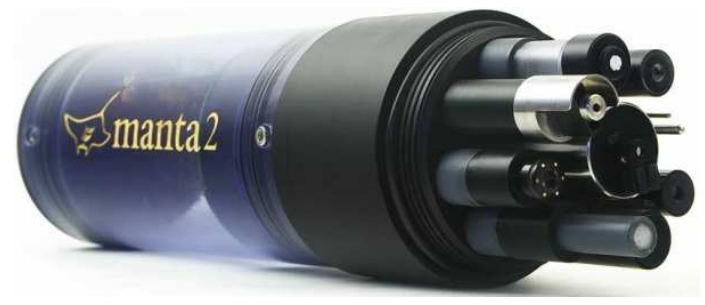

c) multiprobe system [19] type of probes, protocol, etc.). Preferred way of our resolution of is outlined in the last section.

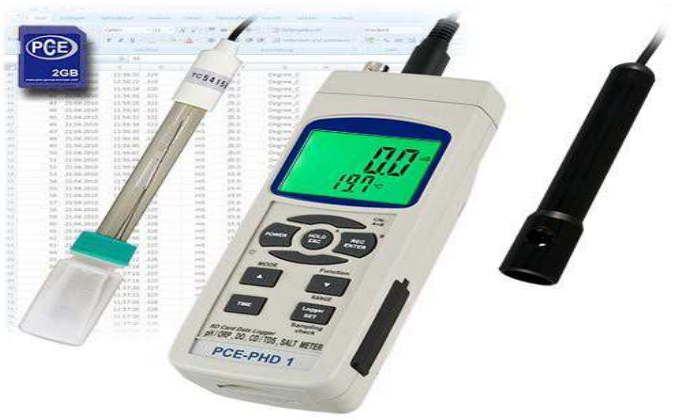

b) multimeter for more parameters of solutions [34]

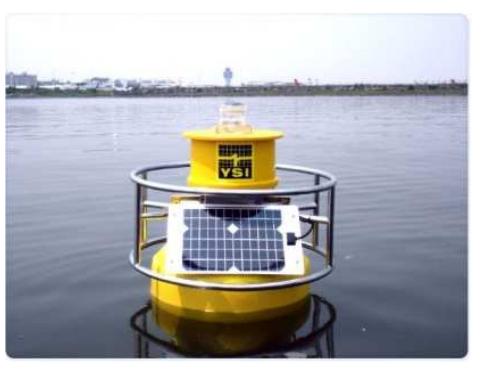

d) floating buoy with solar powering [18]

Fig. 4 Illustrations of the professional sensors and measurement systems

\section{ACKNOWLEDGMENTS}

This work is supported by the project Wireless Sensor Network for wAter QaUAlity Monitoring (WSN-AQUA) (registration number: HUSK/1101/1.2.1/0091).
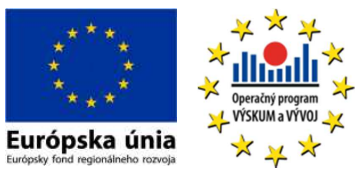

We support research activities in Slovakia / Project is co-financed from EU funds. This paper was developed within the Project "Centrum excelentnosti integrovaného výskumu a využitia progresívnych materiálov a technológií v oblasti automobilovej elektroniky", ITMS 26220120055.

Our particular thanks belong to the SHMI, WRI and Slovak Water Management Enterprise - Bodrog and Hornad branch river basins managements for consultations.

\section{REFERENCES}

[1] Health Canada: www.hc-sc.gc.ca/ewhsemt/pubs/water-eau/ph/index-eng.php\#n2. Reprinted in 1995.

[2] Emerson Process management: Theory and Practice of $\mathrm{pH}$ Measurement. PN 44-6033/rev. D. Rosemount Analytical Inc., USA, 2010.

[3] 2008/105/EC - DIRECTIVE 2008/105/EC OF THE EUROPEAN PARLIAMENT AND OF THE COUNCIL of 16 December 2008 on environmental quality standards in the field of water policy.
[4] DIRECTIVE 2000/60/EC OF THE EUROPEAN PARLIAMENT AND OF THE COUNCIL of 23 October 2000 establishing a framework for Community action in the field of water policy.

[5] Directive No. 269 of Slovak republic government with requirements for good state of water bodies. 2010.

[6] Zákon 364 z 13. mája 2004 o vodách a o zmene zákona Slovenskej národnej rady č. 372/1990 Zb. ... .pdf (so called "Water Law of Slovak Republik").

[7] Advanticsys:

http://www.advanticsys.com/services/smart-watermonitoring/.

[8] RS Hydro: http://www.rshydro.co.uk/Water-QualitySensors-c-254.html.

[9] US Environmental Protection Agency: http://water.epa.gov/learn/resources/measure.cfm. 2012.

[10] US Geological Survey: http://water.usgs.gov/edu/characteristics.html. 2014.

[11] Water Plan of the Slovak Republik; Ministry of Environment of the Slovak Republic, 2010.

[12] SDI-12 Support Group, USA: http://www.sdi12.org/.

[13] MIJOVIC, S. - PALMAR, B.: Water Quality Monitoring Automation of Rivers in Serbia. Facta Universitatis, Series: Working and Living Environmental Protection Vol. 9, No 1, 2012, pp. 1 10. 
[14] SAWI MESS - REGELTECHNIK, A. G: Pt100/Pt1000 platinum resistance thermometer. September 2012.

[15] Emerson Process Management, Liquid Division, Irvine, CA 92606 USA, C) Rosemount Analytical Inc. 2008: FUNDAMENTALS OF ORP MEASUREMENT, Application Data Sheet, ADS 43-014/rev.B, May 2008.

[16] ADAMKOVÁ, J. - ĎURKOVIČOVÁ, D. Mikuličková, M.: State of the Uh River is observed by the warning monitoring station in Pinkovce, Enviromagazin, 5/2000, p. 10.

[17] WINKLER, S. - RIEGER, L. - SARACEVIC, E. PRESSL, A. - GRUBER, G.: Application of ionsensitive sensors in water quality monitoring. Water Science and Technology, Vol. 50, No. 11, pp. 105114. IWA Publishing 2004.

[18] YSI Integrated Systems and Services: http://www.ysisystems.com/floating-platformselector.php.

[19] HydroTerra Pty Ltd., Australia: http://www.hydroterra.com.au/products/surfacewater-quality-measurement-and-logging.

[20] LI, X. - MEIJER, G. C. M.: A Low-Cost and Accurate Interface for Four-Electrode Conductivity Sensors. IEEE Transactions on Instrumentation and Measurement, Vol. 54, No. 6, Dec. 2005. pp. 24332437.

[21] IC Controls, Canada: Technical Notes, The conductivity - Theory and measurement. 2005.

[22] Radiometer Analytical SAS - a Hach Company Brand: $\mathrm{pH}$ theory and practice.

[23] National Instruments: NI-tutorial_2870.

[24] Fondriest Environmental Inc.: Fundamentals of Environmental measurements (http://www.fondriest.com/environmentalmeasurements/equipment/measuring-water-quality).

[25] Van London - Phoenix Co.:Education Series, Conductivity Guide. Glenmont Dr. Houston, USA.

[26] Emerson Process Management: ADS 43-018/Rev.D. - Theory and Application of Conductivity. Jan.2010.

[27] Oakton Instruments: Tech Tips, http://www.aptinstruments.com/pdf/DOCompare(25) .pdf.

[28] Hach-Lange, http://ldo.hach-lange.sk/ldosc.php?gclid=CJb-zpmpn78CFaPItAodLycAfA.

[29] PyroScience Sensor Technology: http://www.pyroscience.com/optical_oxygen_meter_firesting_O2.ht ml. 2014.
[30] IUPAC publications: Compendium of Analytical Nomenclature. Def. rules 1997.

[31] Microsens: ISFET, Product Specific Data Sheet http://www.microsens.ch/products/pdf/MSFET_d atasheet $\% 20$.pdf.

[32] Hach Company, USA: http://www.hach.com/ISFET. 2014.

[33] BARTÍK, I. and all: Hodnotenie ekol.stavu vodných tokov v SR, čast' 1.: Princípy hodnotenia. Vodohosp. spravodajca č. 5-6/2008, pp. 8-10.

[34] PCE instruments UK Ltd.: Manual PCE PHD 1.

[35] AHLBORN měřicí a regulační technika s.r.o., Praha: http://www.ahlborn.cz/cidla-snimace/prochemicke-veliciny/ph-sonda-pher.html.

[36] STM Products, Italy: http://www.stmproducts.com/en/prod/11/Electroniccontrols/28/ovens/48/deck-electric-ovenDEOC.html.

[37] WINKLER, S. - PRESSL, A. - GRUBER, G. ECKER, M. - FLEISCHMANN, N.: Innovative technology for integrated water quality measurement. Proceedings International IWA Conference, Automation in Water Quality Monitoring AutMoNet 2002, May 21-22, 2002, Vienna, pp. 361-368.

Received February 21, 2014, accepted June 4, 2014

\section{BIOGRAPHIES}

Ludmila Maceková was born in Košice, 1959, Slovakia. She graduated (MSc. equiv. degree) in Radioelectronics from the Technical University of Košice in 1983. She received $\mathrm{PhD}$. degree in Telecommunications in 2005 from the same university. Since 1991 she works at this university with Department of Electronics and Multimedia Communications of the Faculty of Electrical Engineering and Informatics, currently as assistant professor. She is working in both education and research areas of image processing, and telecommunications.

Matej Žiga was born on 01.08.1987. In 2012 he graduated (MSc) at the department of Electronics and Multimedia Communications of the Faculty of Electrical Engineering and Informatics at Technical University in Košice, his thesis title was " Design of Ultra-wide band (UWB) applications“. Since 2013 he is working as a scientific - researcher with the Department of Electronics and Multimedia Communications. His scientific research is focusing on impedance spectroscopy for UWB applications, he also investigates questions related with high frequency PCB design. 